\title{
Shaking Table Tests of Low-Rise Shear Walls Made of Recycled Aggregate Concrete
}

\author{
Jianwei Zhang, Dr.; Hongying Dong, Dr.; Wanlin Cao, Dr.; College of Architecture and Civil Eng., Beijing Univ. of technology, \\ Beijing-China; Cheng Yu, Dr.; Dept. of Eng. Technology, Univ. of North Texas, Denton, USA and Yanzhong Chi, Master, Civil Eng.; \\ College of Architecture and Civil Eng., Beijing Univ. of Technology, Beijing-China. Contact: zh_j_wei@sina.com
}

DOI: $10.2749 / 101686616 X 14480232444441$

\begin{abstract}
Experimental studies on the structural reinforced-concrete shear wall members using recycled aggregate concrete (RAC) have been focusing on static loading conditions. The dynamic tests on the reinforced concrete members made of RAC are fairly few. Shaking table tests are necessary because it is difficult to predict the influence of variations in particular properties on the overall dynamic behaviour of the reinforced RAC shear walls made of various mixed materials. The aim of the research work presented in this paper was to investigate the dynamic behaviour of shear walls made of RAC, with different recycled aggregates and reinforcement arrangements, in comparison with shear walls made of natural aggregate concrete (NAC). Five low-rise shear walls were tested in this project: a shear wall made of NAC, a shear wall made of recycled coarse aggregate concrete, and three shear walls made of recycled coarse and recycled fine aggregate concrete with different reinforcement arrangements. Dynamic characteristics and responses of all specimens at different loading stages were determined experimentally, and a comparison of failure modes was presented. The earthquake response time-history analysis of each specimen was also conducted using the finite element software ABAQUS. The ABAQUS results showed good agreement with the test results. The comparison of results showed that, when the reinforcement arrangement was the same, the seismic performance of the shear wall made of recycled coarse and recycled fine aggregate concrete was weakened greatly compared with that of the shear wall made of NAC. The seismic performance of the shear wall made of recycled coarse aggregate concrete was similar to that of the shear wall made of NAC. The seismic resistance capacity of the shear wall made of RAC could be greatly improved by installing concealed bracings.
\end{abstract}

Keywords: recycled aggregate concrete; low-rise shear wall; concealed bracing; shaking table test; time-history response analysis.

\section{Introduction}

The use of recycled waste concrete has two main environmental benefits: managing the growing waste disposal crisis and protecting depleted natural sources of aggregates. In recent years, it has also become an economical solution for concrete construction as the prices of natural aggregates and the cost of waste storage were increasing significantly in many regions. ${ }^{1}$ China is one of the largest resource consumers in the world but with shortage of natural resources; however, its economic



Paper received: March 20, 2015

Paper accepted: September 20, 2015 aggregate was also issued and implemented in $2011 .^{3}$

In order to meet the requirements of structural applications using RAC, plenty of research results about material properties of RAC have been made available in recent years. ${ }^{4-7}$ These results indicated that the amount of recycled aggregates utilised had remarkable influence on the compressive strength of concrete. However, it had only a minor influence on the bond strength when the deformed rebar was applied. For the plain rebar, the bond strength decreases with the increase in the recycled aggregate replacement ratio. The shape of the stress-strain curves of RAC was similar to that of natural aggregate concrete (NAC), but the slope of the stress-strain curves decreased. Some results about basic mechanical properties and hysteretic behaviour of structural reinforced concrete members made of RAC have also been achieved, such as beam, ${ }^{1,8}$ column, ${ }^{1,9}$ beam-column joint, ${ }^{10}$ shear wall, ${ }^{11}$ frame ${ }^{12,13}$ and frameshear wall. ${ }^{14}$ By comparing the results obtained, it can be noted that, when recycled coarse aggregate instead of natural gravel was used, the bearing capacity and hysteretic behaviour of members was similar, but the deformation of members made of RAC was greater. The members made of RAC showed adequate structural behaviour, so they could be applied in actual structures under the proper design and within the proper limit of application. Those research achievements provide reliable test data for the application of RAC in building structures. But majority of those experimental results were obtained by means of static testing. Experimental studies on dynamic behaviour of structural reinforced concrete members made of RAC are fairly few. To better understand the effect of recycled aggregate replacement ratio on dynamic behaviour of RAC members under earthquake action, this paper presents an experimental investigation of the dynamic behaviour 
of shear walls made of RAC by conducting shaking table tests. Five lowrise shear walls were tested, and the research focused on the influences of different recycled aggregate replacement ratio and reinforcement arrangements on the shear wall performance.

\section{Experimental Details}

\section{Design of the Specimens}

In order to reduce the size effect under consideration of the capacity of the shaking table, the reduction scale for the specimen was determined as $1: 3$ (a reduction scale used usually in the static testing of reinforced concrete shear wall). According to the similitude requirements, five $1: 3$ scale low-rise shear wall specimens were designed and constructed in this project. The similitude coefficient of specimens is provided in Table 1. The five shear wall specimens were labelled as SW1, SW2, SW3, SW4 and SW5. SW1 was made of NAC. SW2 was made of recycled coarse aggregate concrete. SW3, SW4 and SW5 were made of recycled coarse and recycled fine aggregate concrete. As presented in Table 2, the specimens SW1, SW2 and SW3 had the same reinforcement as SW5, except for the concealed bracings. ${ }^{15} \mathrm{SW} 4$ had the same total amount of reinforcement as SW5, whereas the difference between the two was that SW5 had concealed bracings but SW4

\begin{tabular}{|l|c|l|c|}
\hline $\begin{array}{l}\text { Physical } \\
\text { quantity }\end{array}$ & $\begin{array}{c}\text { Ratio of similitude } \\
\text { (specimen/prototype) }\end{array}$ & Physical quantity & $\begin{array}{c}\text { Ratio of similitude } \\
\text { (specimen/prototype) }\end{array}$ \\
\hline Strain $\varepsilon$ & 1 & Linear displacement $x$ & $1 / 3$ \\
\hline Stress $\sigma$ & 1 & Acceleration $a$ & 1 \\
\hline $\begin{array}{l}\text { Elastic } \\
\text { modulus } E\end{array}$ & 1 & Time $t$ & $(1 / 3)^{1 / 2}$ \\
\hline Stiffness $K$ & $1 / 3$ & Mass $m$ & $1 / 9$ \\
\hline
\end{tabular}

Table 1: Similitude coefficient of specimens bracings linking the boundary columns onal cracks, and the stiffness of shear walls obviously improved after conwalls made of RAC. All five specimens had the same overall dimensions. The sections of the specimens were 70 and $600 \mathrm{~mm}$, respectively. A $170 \mathrm{~mm}$ was loaded to the specimen at middepth of the top beam. D8 (diameter ary region and concealed bracing. D4 the concealed bracing and the distributing bars in the web region. Table 3 steel bars. The test specimens were made of fine stone concrete and the size distribution of coarse aggregate was $5-10 \mathrm{~mm}$. The designed concrete C30. The fine natural aggregate and did not. The experimental results of the NAC shear walls with concealed bracings showed that, due to concealed and concealed beams to yield truss behaviours, and concealed bracings could restrict the development of diagcrete cracking. This made it possible to restrain greater deformation of shear dimensions and reinforcement layout of the specimens are shown in Fig. 1. The thickness and length of the cross$\times 250 \mathrm{~mm}$ deep beam was cast on top of the wall panel, and additional mass $=8 \mathrm{~mm}$ ) steel bars were used for the longitudinal reinforcement of bound(diameter $=4 \mathrm{~mm}$ ) galvanised iron wires were used for the stirrups of the boundary region, the cross-ties of lists the mechanical properties of the strength grade for the specimens was

\begin{tabular}{|l|c|c|c|c|c|}
\hline \multirow{2}{*}{ Recycled aggregate } & SW1 & SW2 & SW3 & SW4 & SW5 \\
\cline { 2 - 6 } & $\mathbf{0}$ & $\begin{array}{c}\text { Coarse } \\
\text { aggregate }\end{array}$ & $\begin{array}{c}\text { Coarse and } \\
\text { fine aggregate }\end{array}$ & $\begin{array}{c}\text { Coarse and } \\
\text { fine aggregate }\end{array}$ & $\begin{array}{c}\text { Coarse and } \\
\text { fine aggregate }\end{array}$ \\
\hline Horizontal web reinforcement (mm) & $\mathrm{D} 4 @ 125$ & $\mathrm{D} 4 @ 125$ & $\mathrm{D} 4 @ 125$ & $\mathrm{D} 4 @ 65$ & $\mathrm{D} 4 @ 125$ \\
\hline Horizontal web reinforcement ratio (\%) & 0.29 & 0.29 & 0.29 & 0.55 & 0.29 \\
\hline Vertical web reinforcement (mm) & $\mathrm{D} 4 @ 125$ & $\mathrm{D} 4 @ 125$ & $\mathrm{D} 4 @ 125$ & $\mathrm{D} 4 @ 65$ & $\mathrm{D} 4 @ 125$ \\
\hline Vertical web reinforcement ratio (\%) & 0.29 & 0.29 & 0.29 & 0.55 & 0.29 \\
\hline Longitudinal reinforcement in concealed bracings & 0 & 0 & 0 & 0 & $4 \mathrm{D} 8 \mathrm{~mm}$ \\
\hline One-legged ties in concealed bracings & 0 & 0 & 0 & 0 & $\mathrm{D} 4 @ 70 \mathrm{~mm}$ \\
\hline Total reinforcement ratio in wall body (\%) & 0.58 & 0.58 & 0.58 & 1.10 & 1.10 \\
\hline Longitudinal reinforcement in boundary elements (mm) & $8 \mathrm{D} 8$ & $8 \mathrm{D} 8$ & $8 \mathrm{D} 8$ & $8 \mathrm{D} 8$ & $8 \mathrm{D} 8$ \\
\hline Stirrups in boundary elements (mm) & $\mathrm{D} 4 @ 70$ & $\mathrm{D} 4 @ 70$ & $\mathrm{D} 4 @ 70$ & $\mathrm{D} 4 @ 70$ & $\mathrm{D} 4 @ 70$ \\
\hline
\end{tabular}

Table 2: Properties of specimens coarse natural aggregates were of the kind used typically in ready-mix concrete construction in North China. The waste concrete was from the beams and columns of a demolished $\mathrm{RC}$ frame structural project in $\mathrm{Xi}$ Dan of Beijing, having original concrete strength grade of $\mathrm{C} 20$. The waste concrete was processed into recycled aggregates by a local construction and demolition recycling plant. The recycled fine aggregate and coarse aggregate were of the second level specified in Chinese Code GB/T 25176-2010 16 and GB/T 25177-2010 ${ }^{17}$, respectively. The mix proportion and mechanical property of the concrete are listed in Table 4. The shaking table tests were conducted at the Key Laboratory of Urban Security and Disaster Engineering at the Beijing University of Technology, Beijing, China. The dimensions of the table were $3 \mathrm{~m} \times$ $3 \mathrm{~m}$; the maximum load capacity was $10 \mathrm{t}$; the frequency was $0.1-0.5 \mathrm{~Hz}$; the acceleration could reach $2.5 \mathrm{~g}$ without load or $1.0 \mathrm{~g}$ with full load; vibration was along the single horizontal direction. The gravity load trough was fixed to the specimen by bolts, and construction measures were taken carefully to make sure that there was no relative displacement between the load trough and the specimen. The distance from the fixed bolts to the wall base was $600 \mathrm{~mm}$, resulting in a nominal aspect ratio of $1: 1$ for the specimen. To maintain in-plane stability of the shear wall during the test, four supporting poles were installed around the specimen and were connected to the load trough by slide bolts. The whole test device is shown in Fig. 2. The designed axial compression ratio of the shear wall was 0.12 , but the mass of the wall was only $0.063 \mathrm{t}$, so that the added mass at the top of the specimen was $7 \mathrm{t}$. The distance from the counterweight's centroid to the wall base was $975 \mathrm{~mm}$. 
(a)


(b)
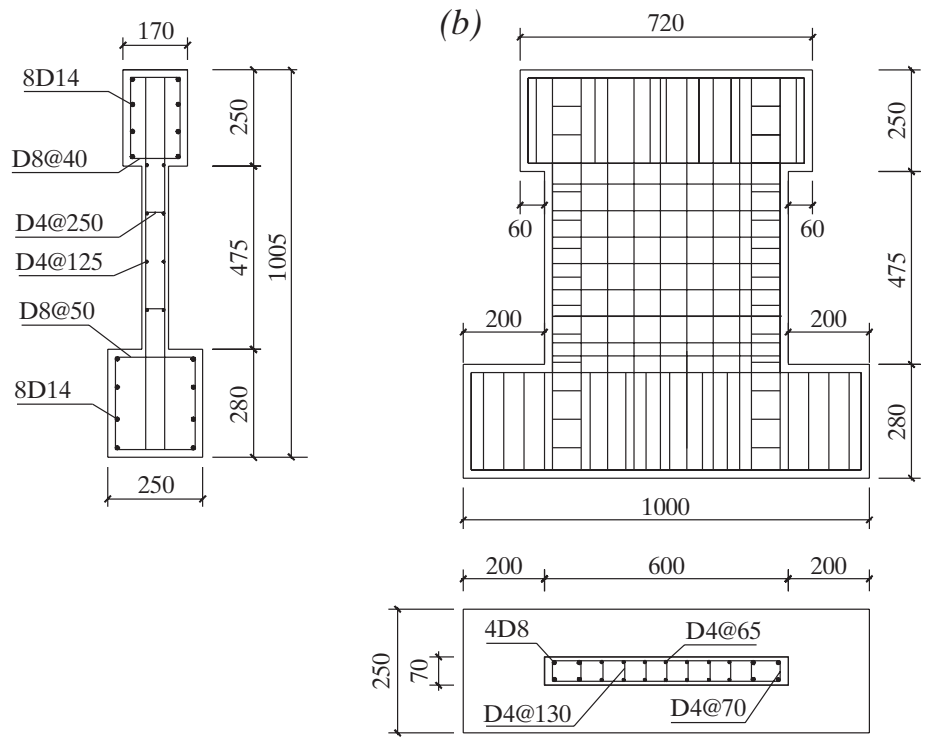

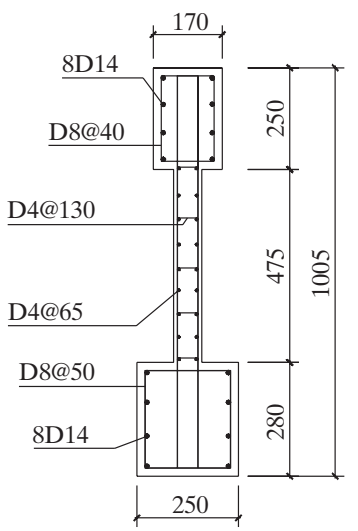

(c)


Fig. 1: Steel rebar details of specimens (Units in mm). (a) SW1, SW2 and SW3; (b)SW4 and (c) SW5

\begin{tabular}{|l|c|c|c|}
\hline Steel bar & $\begin{array}{c}\text { Yielding strength } \\
\boldsymbol{f}_{\mathbf{y}}(\mathbf{M P a})\end{array}$ & $\begin{array}{c}\text { Ultimate strength } \\
\boldsymbol{f}_{\mathbf{u}}(\mathbf{M P a})\end{array}$ & $\begin{array}{c}\text { Elastic modulus } \\
\left.\boldsymbol{E}_{\mathbf{s}} \mathbf{( M P a}\right)\end{array}$ \\
\hline D4 & 312.42 & 351.68 & $1.79 \times 10^{5}$ \\
\hline D8 & 338.20 & 492.88 & $1.98 \times 10^{5}$ \\
\hline
\end{tabular}

Table 3: Mechanical properties of steel bars

\begin{tabular}{|c|c|c|c|c|c|c|}
\hline \multirow[t]{2}{*}{ Specimen } & \multicolumn{4}{|c|}{ Mix proportion (kg) } & \multirow{2}{*}{$\begin{array}{c}\text { Cubic } \\
\text { compression } \\
\text { strength } f_{\text {cu }}(\mathrm{MPa})\end{array}$} & \multirow{2}{*}{$\begin{array}{c}\text { Elastic } \\
\text { modulus } E_{\mathrm{c}} \\
(\mathrm{MPa})\end{array}$} \\
\hline & Cement & $\begin{array}{c}\text { Fine } \\
\text { aggregate }\end{array}$ & $\begin{array}{c}\text { Coarse } \\
\text { aggregate }\end{array}$ & Water & & \\
\hline SW1 & 100 & 125 & 250 & 50 & 35.5 & $3.13 \times 10^{4}$ \\
\hline SW2 & 100 & 125 & 250 & 53 & 32.6 & $2.68 \times 10^{4}$ \\
\hline SW3-SW5 & 100 & 125 & 250 & 55 & 31.2 & $2.35 \times 10^{4}$ \\
\hline
\end{tabular}

Table 4: Mix proportion and mechanical property of concrete

\section{Test Procedure and Measurements}

The objectives of this experimental research were: (a) to test and compare the natural frequencies and dynamic responses (responses of acceleration, drift and shear force) of the five specimens subjected to various levels of earthquake ground motions, (b) to compare the seismic performance and failure modes among the five specimens.

The five specimens were subjected to shaking table motions that simulate the El Centro (1940) N-S component earthquake ground motions, and the magnitude of peak ground acceleration (PGA) varied over the approximate range of $0.1,0.15,0.2,0.3,0.4 g$ etc. The actual PGA measured by the accelerometer on the surface of the shaking table during the experiment is shown in Table 5. The time scale was compressed by the factor of $\sqrt{1 / 3}$ $=0.577$, according to the similitude law. The scaled values of time interval and duration of time of the earthquake motions were then $0.02 \times 0.577$ $=0.01154 \mathrm{~s}$ and $50 \times 0.577=30.581 \mathrm{~s}$, respectively.

The natural frequency of each specimen was measured through low-amplitude white noise excitation during the test. The test measurements also included the lateral absolute acceleration and drift responses on the roof of each specimen, the lateral absolute acceleration responses at the position 

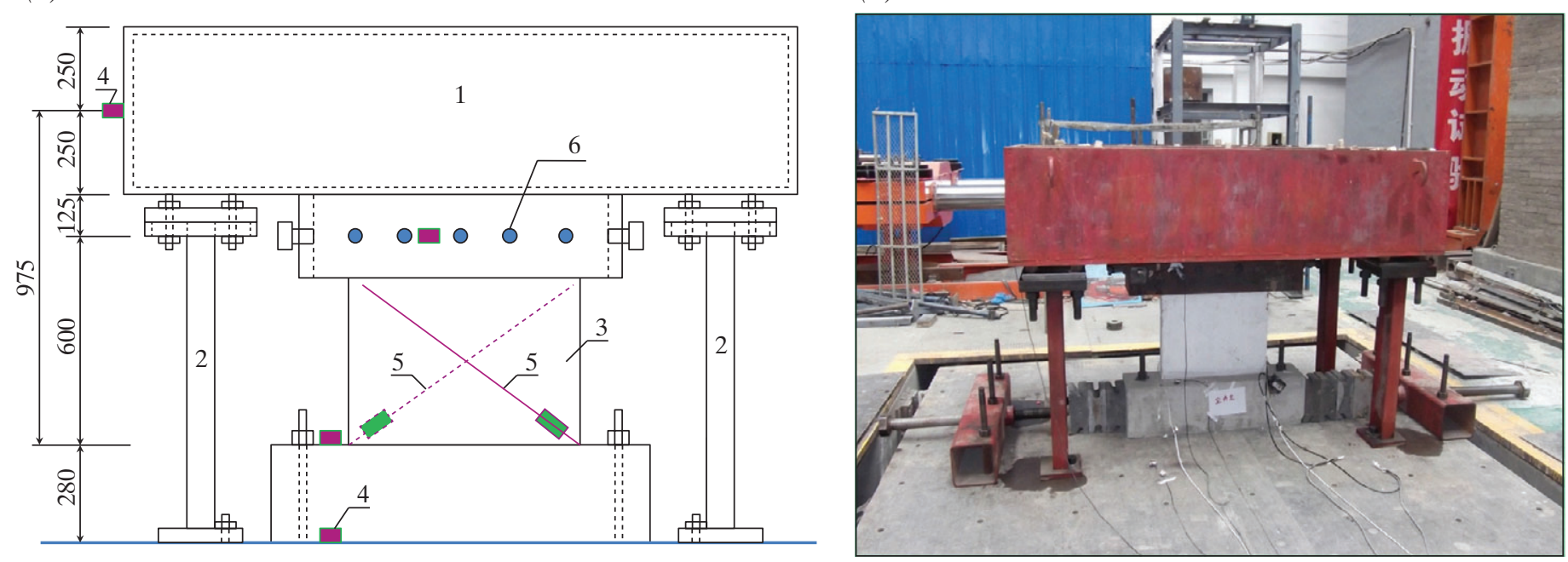

1-Load trough 2-Supporting pole 3-Specimen

4-Accelerometer 5-Displacement meter 6-Bolt

Fig. 2: Test setup. (a) Schematic diagram (Units in $\mathrm{mm}$ ) and (b) photograph

of the counterweight's centroid and at the top of the base, as well as the strain at the end of the longitudinal reinforcement in the boundary region.

\section{Experimental Results and Interpretation}

\section{Natural Frequency of Vibration}

The natural frequency of each specimen measured in different stages is listed in Table 6. The change of the natural frequency reflects the variation characteristics of the specimens' stiffness. The results shown in Table 6 indicate that the natural frequency of the five specimens decreased gradually with the increase in specimens' damage level. This was because the diagonal cracks developed continually and the plastic deformations increased gradually as the experiment progressed. After a similar excitation, the natural frequency of SW1, SW2, SW3, SW4 and SW5 decreased by 18.5, $19.5,21.9,37.1$ and $20.9 \%$, respectively. It showed that the stiffness degradation of shear walls made of RAC increased with the increase in the recycled aggregate replacement ratio. The natural

\begin{tabular}{|c|c|c|c|c|c|}
\hline \multirow{2}{*}{$\begin{array}{c}\text { Signal } \\
\text { number }\end{array}$} & \multicolumn{5}{|c|}{ The peak ground acceleration $(\mathbf{g})$} \\
\hline & SW1 & SW2 & SW3 & SW4 & SW5 \\
\hline 1 & 0.137 & 0.109 & 0.112 & 0.108 & 0.099 \\
\hline 2 & 0.194 & 0.179 & 0.171 & 0.169 & 0.173 \\
\hline 3 & 0.224 & 0.229 & 0.202 & 0.177 & 0.212 \\
\hline 4 & 0.305 & 0.329 & 0.328 & 0.327 & 0.341 \\
\hline 5 & 0.425 & 0.402 & 0.402 & 0.414 & 0.412 \\
\hline 6 & 0.560 & 0.478 & 0.412 & 0.580 & 0.474 \\
\hline 7 & 0.622 & 0.603 & 0.489 & 0.659 & 0.657 \\
\hline 8 & 0.700 & 0.696 & 0.597 & 0.768 & 0.731 \\
\hline 9 & 0.713 & 0.858 & 0.763 & 0.779 & 0.856 \\
\hline 10 & 0.759 & 0.896 & 0.875 & 0.918 & 0.899 \\
\hline 11 & 0.898 & 1.210 & 0.927 & 0.975 & 1.080 \\
\hline 12 & 0.952 & 1.190 & 1.273 & 1.015 & 1.140 \\
\hline 13 & 1.020 & 1.300 & 1.411 & 1.071 & 1.231 \\
\hline 14 & 1.020 & 1.340 & 1.455 & 1.257 & 1.240 \\
\hline 15 & 1.050 & 1.450 & 1.522 & 1.467 & 1.395 \\
\hline 16 & 1.281 & 1.500 & 1.652 & 1.542 & 1.400 \\
\hline 17 & 1.774 & 1.760 & 1.677 & 1.598 & 1.465 \\
\hline 18 & 1.765 & 1.780 & 1.793 & 1.626 & 1.555 \\
\hline 19 & 1.720 & & & 1.789 & 1.602 \\
\hline 20 & 1.760 & & & & 1.826 \\
\hline
\end{tabular}

Table 5: Test procedure

frequency decrement of SW5 was lower than that of SW3 and SW4. The reason was that the bolt pin function of the concealed bracings stayed and restricted the development of diagonal cracks such that the stiffness decrement of SW5 was slower than that of SW3 and SW4. The reinforcement ratio of SW4 was higher than that of SW3, but the natural frequencies decrement of SW4 was faster than that of SW3. This shows that the discreteness of stiffness degradation for shear walls made of recycled coarse and recycled fine aggregate concrete was considerably high. This was because the effect of recycled fine aggregate on the mechanical property of concrete was greater than recycled coarse aggregate, and the quality of structural members made of recycled fine aggregate could not be controlled easily in the construction process.

\section{Acceleration Response}

The measured maximum absolute acceleration responses of the five specimens are listed in Table 7. The comparisons of roof acceleration history responses among five specimens subjected to the strongest earthquake excitation for $3 \mathrm{~s}$, before and after concrete cracking as well as after initial cracks appeared, are shown in Fig. 3. It can be seen from Table 7 and Fig. 3 that under the same level of ground motion, the acceleration responses increased with the increase in recycled aggregate replacement ratio before concrete cracking, and the reinforcement ratio did not have a significant effect on the acceleration responses at this stage. When initial cracks appeared, as shown in Table 6, the shaking table's peak acceleration of 


\begin{tabular}{|c|c|c|c|c|c|c|c|c|c|}
\hline \multicolumn{2}{|l|}{ SW1 } & \multicolumn{2}{|l|}{ SW2 } & \multicolumn{2}{|l|}{ SW3 } & \multicolumn{2}{|l|}{ SW4 } & \multicolumn{2}{|l|}{ SW5 } \\
\hline Test time & $f(\mathbf{H z})$ & Test time & $f(\mathbf{H z})$ & Test time & $f(\mathbf{H z})$ & Test time & $f(\mathbf{H z})$ & \begin{tabular}{|l|} 
Test time \\
\end{tabular} & $f(\mathbf{H z})$ \\
\hline $\begin{array}{l}\text { Before wave } \\
\text { excitation }\end{array}$ & 8.32 & \begin{tabular}{|l} 
Before wave \\
excitation
\end{tabular} & 8.05 & $\begin{array}{l}\text { Before wave } \\
\text { excitation }\end{array}$ & 8.18 & $\begin{array}{l}\text { Before wave } \\
\text { excitation }\end{array}$ & 8.25 & $\begin{array}{l}\text { Before wave } \\
\text { excitation }\end{array}$ & 8.27 \\
\hline $\begin{array}{l}\text { After } 0.224 g \\
\text { wave excitation }\end{array}$ & 8.29 & \begin{tabular}{|l|} 
After $0.229 g$ \\
wave excitation \\
(crack occurred) \\
\end{tabular} & 7.40 & \begin{tabular}{|l|} 
After $0.202 g$ \\
wave excitation \\
(crack occurred) \\
\end{tabular} & 7.36 & \begin{tabular}{|l|} 
After $0.327 g$ \\
wave excitation \\
(crack occurred) \\
\end{tabular} & 7.99 & \begin{tabular}{|l|} 
After $0.341 g$ \\
wave excitation \\
(crack occurred) \\
\end{tabular} & 7.85 \\
\hline $\begin{array}{l}\text { After } 0.305 g \\
\text { wave excitation } \\
\text { (crack occurred) }\end{array}$ & 7.88 & $\begin{array}{l}\text { After } 0.402 g \\
\text { wave excitation }\end{array}$ & 7.15 & $\begin{array}{l}\text { After } 0.597 g \\
\text { wave excitation }\end{array}$ & 7.04 & $\begin{array}{l}\text { After } 0.659 g \\
\text { wave excitation }\end{array}$ & 7.00 & $\begin{array}{l}\text { After } 0.657 g \\
\text { wave excitation }\end{array}$ & 7.37 \\
\hline $\begin{array}{l}\text { After } 0.713 g \\
\text { wave excitation }\end{array}$ & 7.21 & $\begin{array}{l}\text { After } 0.603 g \\
\text { wave excitation }\end{array}$ & 6.80 & $\begin{array}{l}\text { After } 1.411 g \\
\text { wave excitation }\end{array}$ & 6.92 & $\begin{array}{l}\text { After } 1.015 g \\
\text { wave excitation }\end{array}$ & 6.48 & $\begin{array}{l}\text { After } 0.856 g \\
\text { wave excitation }\end{array}$ & 6.90 \\
\hline $\begin{array}{l}\text { After } 1.020 \mathrm{~g} \\
\text { wave excitation }\end{array}$ & 6.82 & $\begin{array}{l}\text { After } 1.190 g \\
\text { wave excitation }\end{array}$ & 6.53 & $\begin{array}{l}\text { After } 1.455 g \\
\text { wave excitation }\end{array}$ & 6.45 & $\begin{array}{l}\text { After } 1.257 g \\
\text { wave excitation }\end{array}$ & 6.08 & $\begin{array}{l}\text { After } 1.231 g \\
\text { wave excitation }\end{array}$ & 6.86 \\
\hline $\begin{array}{l}\text { After } 1.720 g \\
\text { wave excitation }\end{array}$ & 6.78 & $\begin{array}{l}\text { After } 1.760 \mathrm{~g} \\
\text { wave excitation }\end{array}$ & 6.48 & $\begin{array}{l}\text { After } 1.793 \mathrm{~g} \\
\text { wave excitation }\end{array}$ & 6.39 & $\begin{array}{l}\text { After } 1.626 g \\
\text { wave excitation }\end{array}$ & 5.19 & $\begin{array}{l}\text { After } 1.602 g \\
\text { wave excitation }\end{array}$ & 6.54 \\
\hline
\end{tabular}

Table 6: Test results of natural frequency of specimens

\begin{tabular}{|c|c|c|c|c|c|c|c|c|c|}
\hline \multicolumn{2}{|r|}{ SW1 } & \multicolumn{2}{|r|}{ SW2 } & \multicolumn{2}{|r|}{ SW3 } & \multicolumn{2}{|r|}{ SW4 } & \multicolumn{2}{|r|}{ SW5 } \\
\hline $\begin{array}{c}\text { Input } \\
(g)\end{array}$ & \begin{tabular}{|c|}
$\begin{array}{c}\text { Roof acceleration } \\
(\mathrm{g})\end{array}$ \\
\end{tabular} & $\begin{array}{c}\text { Input } \\
(g)\end{array}$ & \begin{tabular}{|c|} 
Roof acceleration \\
$(\mathrm{g})$
\end{tabular} & $\begin{array}{c}\text { Input } \\
(g)\end{array}$ & $\begin{array}{c}\text { Roof acceleration } \\
(g)\end{array}$ & $\begin{array}{c}\text { Input } \\
(g)\end{array}$ & $\begin{array}{c}\text { Roof acceleration } \\
(\mathrm{g})\end{array}$ & $\begin{array}{c}\text { Input } \\
(g)\end{array}$ & $\begin{array}{c}\text { Roof acceleration } \\
(\mathrm{g})\end{array}$ \\
\hline \begin{tabular}{|l|}
0.137 \\
\end{tabular} & 0.155 & 0.109 & 0.117 & 0.112 & 0.103 & \begin{tabular}{|l|l}
0.108 \\
\end{tabular} & 0.125 & \begin{tabular}{|l|}
0.099 \\
\end{tabular} & 0.119 \\
\hline 0.194 & 0.172 & 0.179 & 0.175 & \begin{tabular}{|l|l|}
0.171 \\
\end{tabular} & 0.213 & \begin{tabular}{|l|l|}
0.169 \\
\end{tabular} & 0.187 & \begin{tabular}{|l}
0.173 \\
\end{tabular} & 0.197 \\
\hline 0.224 & 0.231 & 0.229 & 0.208 & \begin{tabular}{|l|l|}
0.202 \\
\end{tabular} & 0.226 & \begin{tabular}{|l|l}
0.177 \\
\end{tabular} & 0.204 & \begin{tabular}{|l}
0.212 \\
\end{tabular} & 0.242 \\
\hline 0.305 & 0.378 & 0.329 & 0.315 & 0.328 & 0.402 & 0.327 & 0.377 & \begin{tabular}{|l|}
0.341 \\
\end{tabular} & 0.363 \\
\hline \begin{tabular}{l|l}
0.425 \\
\end{tabular} & 0.465 & 0.402 & 0.451 & 0.402 & 0.467 & \begin{tabular}{|l|l|}
0.414 \\
\end{tabular} & 0.453 & \begin{tabular}{|l|l}
0.412 \\
\end{tabular} & 0.46 \\
\hline 0.560 & 0.631 & 0.482 & 0.555 & 0.412 & 0.632 & \begin{tabular}{|l|l}
0.580 \\
\end{tabular} & 0.653 & \begin{tabular}{|l|l}
0.474 \\
\end{tabular} & 0.621 \\
\hline 0.622 & 0.883 & 0.603 & 0.858 & \begin{tabular}{|l|l}
0.489 \\
\end{tabular} & 0.715 & \begin{tabular}{|l}
0.659 \\
\end{tabular} & 0.806 & \begin{tabular}{|l}
0.657 \\
\end{tabular} & 0.861 \\
\hline 0.700 & 0.896 & 0.696 & 0.875 & \begin{tabular}{|l}
0.597 \\
\end{tabular} & $\begin{array}{l}0.852 \\
\end{array}$ & \begin{tabular}{|l|l}
0.768 \\
\end{tabular} & 0.892 & \begin{tabular}{|l}
0.731 \\
\end{tabular} & 0.995 \\
\hline \begin{tabular}{|l|l|}
0.713 \\
\end{tabular} & 0.912 & 0.858 & 1.199 & 0.763 & 0.954 & \begin{tabular}{|l|l|}
0.779 \\
\end{tabular} & 0.923 & 0.856 & 1.078 \\
\hline \begin{tabular}{l|l} 
\\
\end{tabular} & 0.925 & 0.896 & 1.431 & 0.875 & 1.271 & \begin{tabular}{|l}
0.918 \\
\end{tabular} & 1.121 & \begin{tabular}{|l}
0.899 \\
\end{tabular} & 1.154 \\
\hline 0.898 & 0.931 & 1.210 & 1.53 & \begin{tabular}{|l|l|}
0.926 \\
\end{tabular} & 1.438 & \begin{tabular}{|l|l|}
0.975 \\
\end{tabular} & 1.125 & 1.080 & 1.297 \\
\hline \begin{tabular}{l|l}
0.952 \\
\end{tabular} & 0.942 & 1.190 & 1.789 & \begin{tabular}{|l|l}
0.927 \\
\end{tabular} & 1.478 & 1.015 & 1.281 & 1.140 & 1.386 \\
\hline 1.020 & 1.021 & 1.300 & 1.835 & 1.273 & 1.784 & \begin{tabular}{|l|l}
1.071 \\
\end{tabular} & 1.321 & 1.231 & 1.452 \\
\hline 1.020 & 1.117 & 1.340 & 1.838 & 1.411 & 1.993 & \begin{tabular}{|l}
1.257 \\
\end{tabular} & 1.654 & 1.240 & 1.498 \\
\hline 1.050 & 1.279 & 1.450 & 2.151 & 1.455 & 2.112 & \begin{tabular}{|l|l}
1.467 \\
\end{tabular} & 1.895 & 1.395 & 1.512 \\
\hline 1.281 & 1.369 & 1.500 & 2.171 & 1.522 & 2.135 & 1.542 & 1.985 & 1.400 & 1.726 \\
\hline 1.774 & 2.21 & 1.760 & 2.192 & \begin{tabular}{|l|l}
1.677 \\
\end{tabular} & 2.178 & 1.598 & 2.106 & 1.465 & 1.911 \\
\hline 1.765 & 2.397 & 1.780 & 2.291 & 1.793 & 2.189 & 1.626 & 2.164 & 1.555 & 2.219 \\
\hline 1.720 & 2.386 & & & & & \begin{tabular}{|l}
1.789 \\
\end{tabular} & 2.419 & 1.602 & 2.338 \\
\hline 1.760 & 2.397 & & & & & & & 1.826 & 2.817 \\
\hline
\end{tabular}

Table 7: Maximum acceleration responses of specimens

SW2 and SW3 were 24.9 and $33.8 \%$, respectively, lower than that of SW1, but the shaking table's peak acceleration of SW4 and SW5 were 7.2 and $11.8 \%$, respectively, higher than that of SW1. It shows that the initial stiffness and lateral resistance of shear walls decreased with the increase in recycled aggregate replacement ratio. This is because the elastic modulus and compressive strength decreased with the increase in recycled aggregate replacement ratio. By increasing the reinforcement ratio or by installing concealed bracings, the principal tensile stress in the wall can be more dis- tributed for reinforcement; especially, for the inclined reinforcement in the concealed bracings, the lateral resistance of the shear wall made of RAC could be improved. When the maximum roof drift angle of the specimens exceeded the limit value 1/120 defined in Chinese Code GB50011, ${ }^{18}$ under the same level of ground motion, the acceleration responses decreased with the increase in recycled aggregate replacement ratio, but increased with the increase in reinforcement ratio. The acceleration responses could be further increased by installing the concealed bracings. The reason was that the increase in recycled aggregate replacement ratio speeds up the development of diagonal cracking. On the contrary, the increase in reinforcement ratio strengthened the bolt pin function of the reinforcement, and restricted the development of diagonal cracking.

\section{Drift Response}

The measured results of each specimen's maximum roof drift angle in different stages are listed in Table 8. It can be seen from Table 8 that when the five specimens were subjected to the 

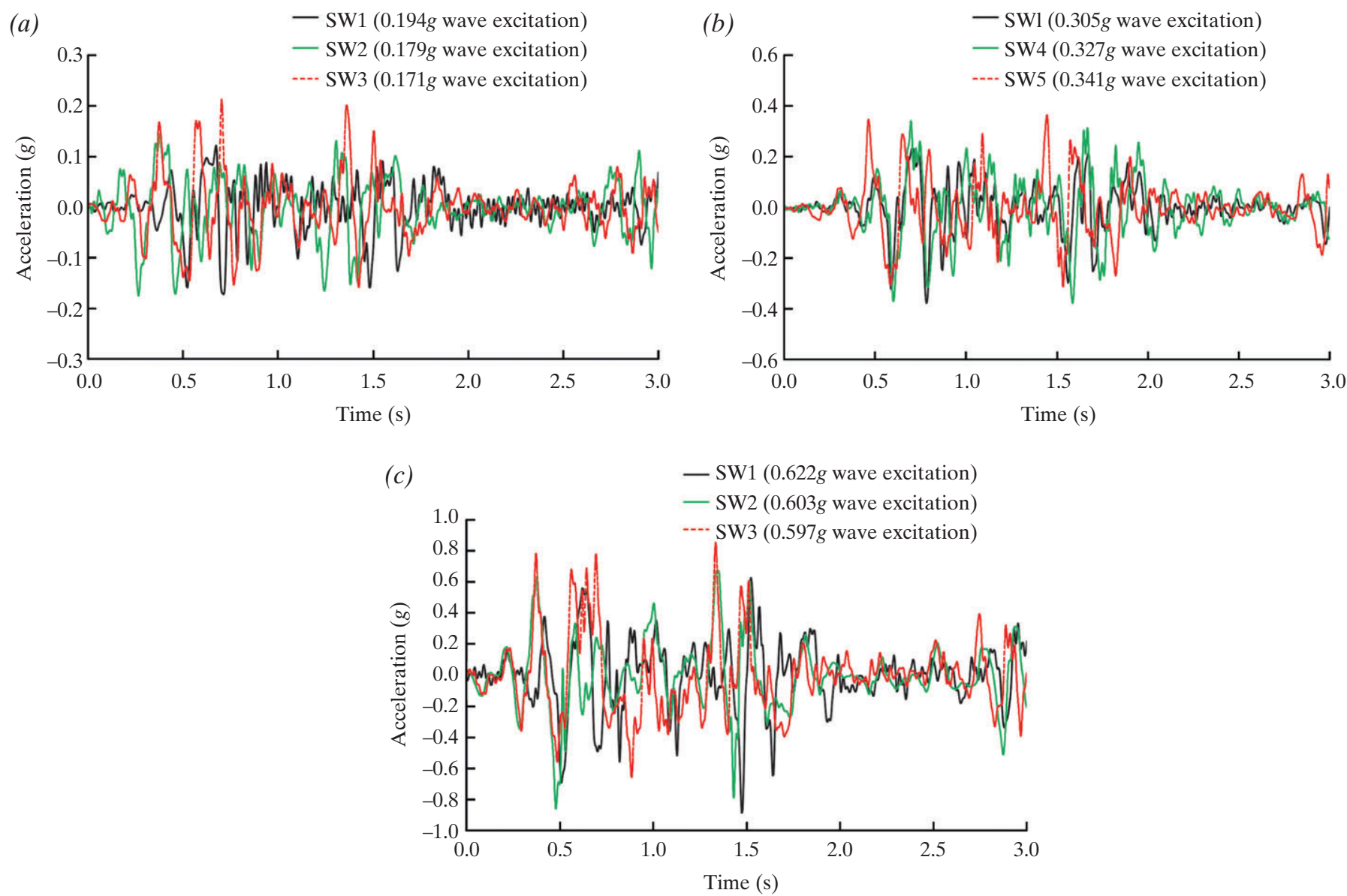

Fig. 3: Time histories of roof accelerations. (a) Before cracking; (b) first cracking; (c) after cracking

\begin{tabular}{|c|c|c|c|c|c|c|c|c|c|}
\hline \multicolumn{2}{|c|}{ SW1 } & \multicolumn{2}{|c|}{ SW2 } & \multicolumn{2}{|c|}{ SW3 } & \multicolumn{2}{|c|}{ SW4 } & \multicolumn{2}{|c|}{ SW5 } \\
\hline Input (g) & $\begin{array}{l}\text { Roof drift } \\
\text { angle }\end{array}$ & Input $(g)$ & $\begin{array}{c}\text { Roof drift } \\
\text { angle }\end{array}$ & Input (g) & $\begin{array}{c}\text { Roof drift } \\
\text { angle }\end{array}$ & Input $(g)$ & $\begin{array}{c}\text { Roof drift } \\
\text { angle }\end{array}$ & Input $(g)$ & $\begin{array}{c}\text { Roof drift } \\
\text { angle }\end{array}$ \\
\hline 0.137 & $1 / 3200$ & 0.109 & $1 / 3548$ & 0.112 & $1 / 2914$ & 0.108 & $1 / 3232$ & 0.099 & $1 / 3627$ \\
\hline 0.194 & $1 / 2205$ & 0.179 & $1 / 3548$ & 0.171 & $1 / 2133$ & 0.169 & $1 / 2162$ & 0.173 & $1 / 2675$ \\
\hline 0.224 & $1 / 1126$ & 0.229 & $1 / 2675$ & 0.202 & $1 / 1784$ & 0.177 & $1 / 1343$ & 0.212 & $1 / 2133$ \\
\hline 0.305 & $1 / 722$ & 0.329 & $1 / 1528$ & 0.328 & $1 / 1525$ & 0.327 & $1 / 1067$ & 0.341 & $1 / 1525$ \\
\hline 0.425 & $1 / 478$ & 0.402 & $1 / 1187$ & 0.402 & $1 / 1187$ & 0.414 & $1 / 629$ & 0.412 & $1 / 1451$ \\
\hline 0.560 & $1 / 396$ & 0.482 & $1 / 1183$ & 0.412 & $1 / 1187$ & 0.580 & $1 / 535$ & 0.474 & $1 / 1187$ \\
\hline 0.622 & $1 / 285$ & 0.603 & $1 / 629$ & 0.489 & $1 / 892$ & 0.659 & $1 / 414$ & 0.657 & $1 / 764$ \\
\hline 0.700 & $1 / 285$ & 0.696 & $1 / 593$ & 0.597 & $1 / 764$ & 0.768 & $1 / 223$ & 0.731 & $1 / 595$ \\
\hline 0.713 & $1 / 278$ & 0.858 & $1 / 534$ & 0.763 & $1 / 566$ & 0.779 & $1 / 194$ & 0.856 & $1 / 428$ \\
\hline 0.759 & $1 / 267$ & 0.896 & $1 / 446$ & 0.875 & $1 / 412$ & 0.918 & $1 / 191$ & 0.899 & $1 / 323$ \\
\hline 0.898 & $1 / 250$ & 1.210 & $1 / 412$ & 0.926 & $1 / 314$ & 0.975 & $1 / 167$ & 1.080 & $1 / 249$ \\
\hline 0.952 & $1 / 238$ & 1.190 & $1 / 382$ & 0.927 & $1 / 289$ & 1.015 & $1 / 149$ & 1.140 & $1 / 232$ \\
\hline 1.020 & $1 / 236$ & 1.300 & $1 / 281$ & 1.273 & $1 / 218$ & 1.071 & $1 / 124$ & 1.231 & $1 / 214$ \\
\hline 1.020 & $1 / 233$ & 1.340 & $1 / 254$ & 1.411 & $1 / 206$ & 1.257 & $1 / 120$ & 1.240 & $1 / 165$ \\
\hline 1.050 & $1 / 164$ & 1.450 & $1 / 232$ & 1.455 & $1 / 188$ & 1.467 & $1 / 119$ & 1.395 & $1 / 147$ \\
\hline 1.281 & $1 / 148$ & 1.500 & $1 / 175$ & 1.522 & $1 / 155$ & 1.542 & $1 / 113$ & 1.400 & $1 / 142$ \\
\hline 1.774 & $1 / 126$ & 1.760 & $1 / 147$ & 1.677 & $1 / 102$ & 1.598 & $1 / 109$ & 1.465 & $1 / 122$ \\
\hline 1.765 & $1 / 122$ & 1.780 & $1 / 109$ & 1.793 & $1 / 88$ & 1.626 & $1 / 101$ & 1.555 & $1 / 120$ \\
\hline 1.720 & $1 / 119$ & & & & & 1.789 & $1 / 88$ & 1.602 & $1 / 109$ \\
\hline 1.760 & $1 / 109$ & & & & & & & 1.826 & $1 / 106$ \\
\hline
\end{tabular}

Table 8: Maximum roof drift angles of specimens

same level of 18th time shaking table motion, the maximum roof drift of SW2, SW3, SW4 and SW5 increased by
$11.8,38.0,20.7$ and $1.4 \%$, respectively, compared with that of SW1. It indicates that under the same peak accel- eration of excitation, the drift response increased with the increase in recycled aggregate replacement ratio, and the 
concealed bracings could decrease the drift response significantly after the concrete cracking started to occur. The reason was that the lateral stiffness decrement of the shear walls increased with the increase in recycled aggregate replacement ratio at the failure stages. For the shear wall with concealed bracings, the concealed bracings restricted the development of diagonal cracks and linked the concealed columns in the boundary regions and the top beam to yield truss behaviours, thereby improving the lateral stiffness greatly.

\section{Base Shear Response}

Under the ground motions, the maximum nominal base shear of each specimen at the moment $t, F_{i}(t)_{\max }$, can be determined as follows:

$F_{i}(t)_{\max }=\left|-m a_{i}(t)\right|_{\max }$

where $m$ is the centralised mass at the roof of the specimen, $a_{i}$ is the centroid acceleration for the $i$ time excitation. The maximum values of the base shear are shown in Table 9. It can be concluded from Table 9 that the earthquake resistance capacity of low-rise shear wall decreased with the increase in recycled aggregate replacement ratio, and it increased with the increase in reinforcement ratio. In addition, the concealed bracings were able to improve significantly the earthquake resistance capacity of low-rise shear walls made of RAC.

\section{Failure Mode}

Figure 4 shows the failure mode of each specimen when the roof drift angle reached the limit value $1 / 120$. It can be seen from Fig. 4 that the cracks in SW2 were less than those in SW1, and the cracks in SW3 were less than those in SW2. The cracks in the shear wall decreased with the increase in the recycled aggregate replacement ratio, but the maximum width of the cracks increased. The cracks in SW4 were more than those in SW3 and the cracks in SW4 were thinner. This shows that the ductility of the low-rise shear walls made of RAC can be improved by increasing the reinforcement ratio. The final failure mode of each specimen is shown in Fig. 5. It can be seen that (a)

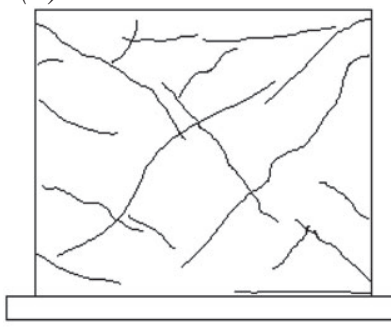

(d)

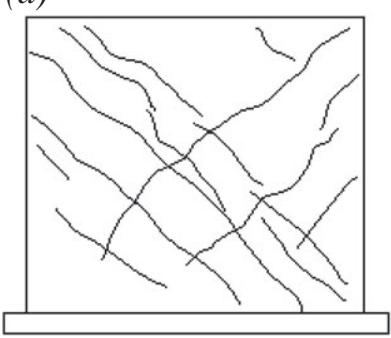

(e)

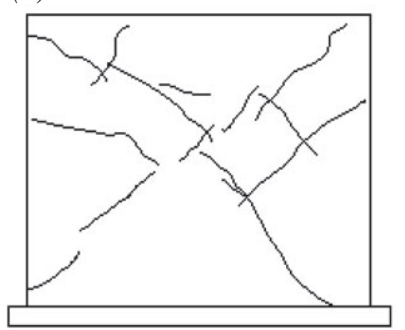

Fig. 4: Failure mode of specimens with 1/120 roof drift angle. (a) SW1, (b) SW2, (c) SW3, (d) SW4 and (e) SW5

\begin{tabular}{|c|c|c|c|c|c|c|c|c|c|}
\hline \multicolumn{2}{|c|}{ SW1 } & \multicolumn{2}{|c|}{ SW2 } & \multicolumn{2}{|c|}{ SW3 } & \multicolumn{2}{|c|}{ SW4 } & \multicolumn{2}{|c|}{ SW5 } \\
\hline Input (g) & $\begin{array}{l}\text { Base shear } \\
\text { (kN) }\end{array}$ & Input (g) & $\begin{array}{l}\text { Base shear } \\
\text { (kN) }\end{array}$ & Input (g) & $\begin{array}{c}\text { Base shear } \\
\text { (kN) }\end{array}$ & Input (g) & $\begin{array}{c}\text { Base shear } \\
(\mathrm{kN})\end{array}$ & Input $(g)$ & $\begin{array}{l}\text { Base shear } \\
(\mathrm{kN})\end{array}$ \\
\hline 0.137 & 10.85 & 0.109 & 8.190 & 0.112 & 7.210 & 0.108 & 8.75 & 0.099 & 8.33 \\
\hline 0.194 & 12.04 & 0.179 & 12.25 & 0.171 & 14.91 & 0.169 & 13.09 & 0.173 & 13.79 \\
\hline 0.224 & 16.17 & 0.229 & 14.56 & 0.202 & 15.82 & 0.177 & 14.28 & 0.212 & 16.94 \\
\hline 0.305 & 26.46 & 0.329 & 22.05 & 0.328 & 28.14 & 0.327 & 26.39 & 0.341 & 25.41 \\
\hline 0.425 & 32.55 & 0.402 & 31.57 & 0.402 & 32.69 & 0.414 & 31.71 & 0.412 & 32.20 \\
\hline 0.560 & 44.17 & 0.482 & 38.85 & 0.412 & 44.24 & 0.580 & 45.71 & 0.474 & 43.47 \\
\hline 0.622 & 61.81 & 0.603 & 60.06 & 0.489 & 50.05 & 0.659 & 56.42 & 0.657 & 60.27 \\
\hline 0.700 & 62.72 & 0.696 & 61.25 & 0.597 & 59.64 & 0.768 & 62.44 & 0.731 & 69.65 \\
\hline 0.713 & 63.84 & 0.858 & 83.93 & 0.763 & 66.78 & 0.779 & 64.61 & 0.856 & 75.46 \\
\hline 0.759 & 64.75 & 0.896 & 100.17 & 0.875 & 88.97 & 0.918 & 78.47 & 0.899 & 80.78 \\
\hline 0.898 & 65.17 & 1.210 & 107.10 & 0.926 & 100.66 & 0.975 & 78.75 & 1.080 & 90.79 \\
\hline 0.952 & 65.94 & 1.190 & 125.23 & 0.927 & 103.46 & 1.015 & 89.67 & 1.140 & 97.02 \\
\hline 1.020 & 71.47 & 1.300 & 128.45 & 1.273 & 124.88 & 1.071 & 92.47 & 1.231 & 101.64 \\
\hline 1.020 & 78.19 & 1.340 & 128.66 & 1.411 & 139.51 & 1.257 & 115.78 & 1.240 & 104.86 \\
\hline 1.050 & 89.53 & 1.450 & 150.57 & 1.455 & 147.84 & 1.467 & 132.65 & 1.395 & 105.84 \\
\hline 1.281 & 95.83 & 1.500 & 151.97 & 1.522 & 149.45 & 1.542 & 138.95 & 1.400 & 120.82 \\
\hline 1.774 & 154.70 & 1.760 & 153.44 & 1.677 & 152.46 & 1.598 & 147.42 & 1.465 & 133.77 \\
\hline 1.765 & 167.79 & 1.780 & 160.37 & 1.793 & 153.23 & 1.626 & 151.48 & 1.555 & 155.33 \\
\hline 1.720 & 167.02 & & & & & 1.789 & 169.33 & 1.602 & 163.66 \\
\hline 1.760 & 167.79 & & & & & & & 1.826 & 197.19 \\
\hline
\end{tabular}

Table 9: Maximum base shears of specimens 
specimen SW3 was the most severely damaged, and specimen SW5 had the slightest damage among the five specimens. The diagonal cracks of SW2 and SW3 had developed into main cracks, resulting in the loss of the earthquake resistance capacity. Because the earthquake resistance capacity and ductility of the low-rise shear walls made of RAC could be greatly improved by concealed bracings, SW5 demonstrated a fairly slight damage level.

All five specimens' failure characteristic was shear failure according to the phenomenon in the tests, as shown in Figs. 4 and 5. When the maximum crack width of the five specimens reached $0.2 \mathrm{~mm}$ after the test, the shaking table's peak acceleration of SW1, SW2, SW3, SW4 and SW5 were $1.281,1.21,0.926,1.015$ and $1.231 \mathrm{~g}$ respectively. Compared with specimen SW1, the PGA for specimens SW2, SW3, SW4 and SW5 were decreased by $5.5,27.7,20.8$ and $3.9 \%$ respectively. At the final failure, the maximum roof drift of SW2 and SW5 was almost the same as that of SW1, while the maximum roof drift of SW3 and SW4 was increased greatly compared with that of SW1. Thus, the seismic performance of SW2 and SW5 was close to that of SW1.

\section{Finite Element Simulation}

Finite element models of RC shear walls can be classified into two types: macroscopic elements and microscopic elements. For the bearing walls dominated by flexure, a macroscopic model consisted of using multi-layered two dimensional (2D) Bernoulli-beam elements coupled with continuum damage mechanics can be used. ${ }^{19}$ In order to include the shear behaviour of walls, several macroscopic models that were able to take into account the flexural-shear interaction were proposed in literature. ${ }^{20-22}$ To simulate damage of squat RC shear walls under lateral loads, a simplified model based on concepts and methods of damage and fracture mechanics was proposed..$^{23}$ Because macroscopic elements are simplified analytical models, they require relatively limited storage and much less computational effort than the microscopic elements. However, it is difficult to determine the appropriate parameters of simplified constituent elements for different types of RC walls.

ABAQUS, a general purpose finite element analysis program, is widely used to analyse mechanical, structural and civil engineering problems. It is traditionally known as a non-linear finite element analysis software package. ABAQUS is capable of conducting both linear and non-linear analyses with various material models and timedependent analysis tools. Therefore, ABAQUS6. $1^{24}$ was selected for the simulation analysis of each specimen. Figure 6 shows the mesh of the shear wall. The ABAQUS models were based on the measured mechanical properties of concrete and steel bars. Steel bars were defined as isotropic elastic-plastic material. The damageplasticity model was used for NAC and RAC. The uniaxial tension and compression stress-strain equations from the Chinese Code GB50010 25 were used for the constitutive relation, as presented in Eqs. (2) and (3).

$\sigma=\left(1-d_{\mathrm{t}}\right) E_{\mathrm{c}} \varepsilon$

$\sigma=\left(1-d_{\mathrm{c}}\right) E_{\mathrm{c}} \mathcal{E}$

where $\sigma$ is the concrete stress, $\varepsilon$ is the concrete strain, $d_{\mathrm{t}}$ is the damaged parameter of concrete in tension, $d_{\mathrm{c}}$ is the damaged parameter of concrete in compression and $E_{\mathrm{c}}$ is the elastic modulus of concrete.

The damaged parameter of concrete in tension or compression is obtained from Eqs. (4) and (5).

When $x \leq 1, d_{\mathrm{t}}=1-\rho_{\mathrm{t}}\left[1.2-0.2 x^{5}\right]$

When $x>1, d_{\mathrm{t}}=1-\rho_{\mathrm{t}} /\left[\alpha_{\mathrm{t}}(x-1)^{1.7}+x\right]$

where $x=\varepsilon \varepsilon^{\prime} ; \rho_{\mathrm{t}}=f_{\mathrm{t}}^{*} /\left(E_{\mathrm{c}} \mathcal{E}_{\mathrm{t}}\right) ; f_{\mathrm{t}}^{*}$ is the uniaxial tensile strength; $\varepsilon_{\mathrm{t}}$ is the corresponding peak tensile strain with $f_{t}^{*}$. $\alpha_{\mathrm{t}}$ is the parameter at the descent stage of the concrete tensile stress-strain curves and its value can be obtained in Chinese Code GB50010 according to $f_{\mathrm{t}}^{*}$.

When $x \leq 1, d_{\mathrm{c}}=1-\rho_{\mathrm{c}} n /\left(n-1+x^{n}\right)$

When $x>1, d_{\mathrm{c}}=1-\rho_{\mathrm{c}} /\left[\alpha_{\mathrm{c}}(x-1)^{2}+x\right]$

where $x=\varepsilon / \varepsilon_{\mathrm{c}} ; \rho_{\mathrm{c}}=f_{\mathrm{c}}^{*} /\left(E_{\mathrm{c}} \varepsilon_{\mathrm{c}}\right) ; n=E_{\mathrm{c}}$ $\varepsilon\left(E_{\mathrm{c}} \varepsilon-f_{\mathrm{c}}^{*}\right) ; f_{\mathrm{c}}^{*}$ is the uni-axial prismatic compression strength; $\varepsilon_{\mathrm{c}}$ is the (a)

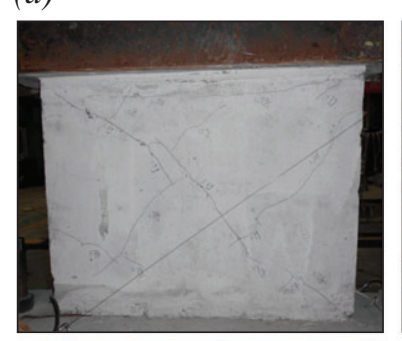

(b)

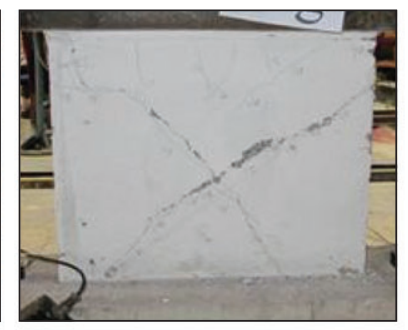

(d)



(e)

(c)
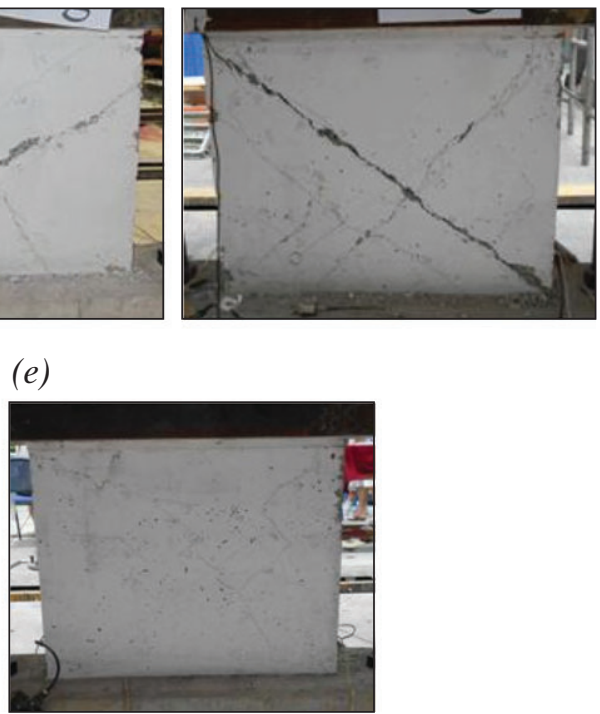

Fig. 5: Final failure mode of specimens. (a) SW1, (b) SW2, (c) SW3, (d) SW4 and (e) SW5

Fig. 6: Finite element mesh in ABAQUS 
corresponding peak compression strain with $f_{\mathrm{c}}^{*} ; \alpha_{\mathrm{c}}$ is the parameter at the descent stage of concrete compression stress-strain curves and its value can be obtained in Chinese Code GB50010 according to $f_{\mathrm{c}}^{*}$.

In the ABAQUS modelling, steel bars and concrete were separated, and the truss element T3D2 and solid element C3D8R were respectively used for the element type of steel bars and concrete. The T3D2 is a linear, three-dimensional (3D), two-node rod that can carry only tensile or compressive loads. The C3D $8 \mathrm{R}$ is a $3 \mathrm{D}$ eight-node hexahedral element, and it is linear with reduced integration.
The constraint relation of Embedded was used to simulate the interaction between the steel bars and the concrete. The added mass on the top of the models was defined as "point mass", and assigned to the central node of the loading beam to simulate the axial pressure and the inertial force generated by the added mass. In order to simulate the energy dissipation in the models, the material damping was defined in the material property and the damping coefficient of $5 \%$ was defined in the point mass definition. In the analysis process, the general static step was created first, and then the gravity load was applied on the whole model and was propagated in the following steps. Then an implicit dynamic step was created and measured acceleration boundary conditions were applied to the bottom surface of the wall panel.

Based on the above modelling, the linear perturbation step in ABAQUS was used to obtain the initial frequency of the specimens. ${ }^{26}$ The calculated initial frequency for specimens SW1, SW2, SW3, SW4 and SW5 was 9.45, 8.92, 8.45, 9.20 and $9.31 \mathrm{~Hz}$, respectively. Compared with the measured initial frequency, the error was $13.6,10.8,3.3,11.5$ and $12.6 \%$, respectively.
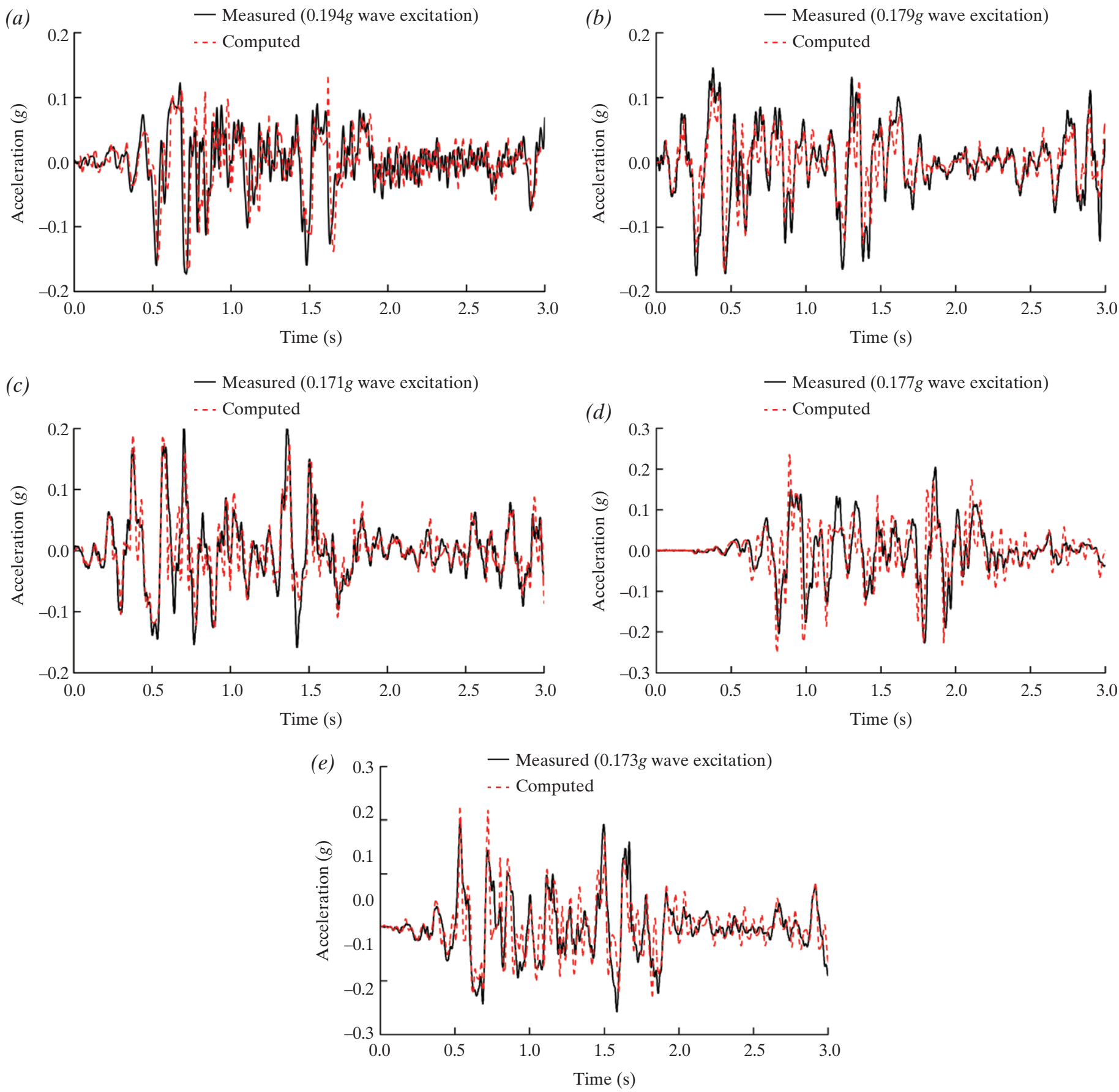

Fig. 7: Comparison of roof acceleration time histories before cracking. (a) SW1, (b) SW2, (c) SW3, (d) SW4 and (e) SW5 
The dynamic analysis at the elastic stage and elastic-plastic stage for the five specimens was carried out. The acceleration responses at different stages were extracted from the analysis results, and were compared with the measured results. Before concrete cracking, the peak acceleration of the input seismic waves for specimens SW1, SW2, SW3, SW4 and SW5 was $0.194,0.179,0.171,0.177$ and $0.173 g$, respectively. The comparison of measured-to-calculated values for the roof acceleration history response in the elastic stage of the five specimens is shown in Fig. 7. When initial cracks appeared, the comparison of measured-to-calculated values for the roof acceleration history response of the five specimens is shown in Fig. 8. After concrete cracking, the peak acceleration of the input seismic waves for specimens SW1, SW2, SW3, SW4 and SW5 was $0.622,0.603,0.597,0.580$ and $0.657 g$, respectively. The comparison of measured-to-calculated values for the roof acceleration history response in the elastic-plastic stage of the five specimens is shown in Fig. 9. It can be seen from Figs. 7 and 8 that the calculated results of each specimen are in a good agreement with the tested results at both the elastic stage and the first cracking stage. It can be seen from Fig. 9 that the calculated result of specimen SW1 made of NAC is in a good agreement with the measured result after cracking, and the calculated results of the other four specimens made of RAC are in reasonable agreement with the measured results. With the increasing degree of damage, the effect of cumulative damage on the computed results increased, resulting in an increase in the computational error. When close to the shear walls collapse, the effect of cumulative damage on the computed results could not be ignored, and the complex problem needed further research. In general, the numerical simulation analysis method used for shear walls made of NAC can be used for analysis of shear walls made of RAC.
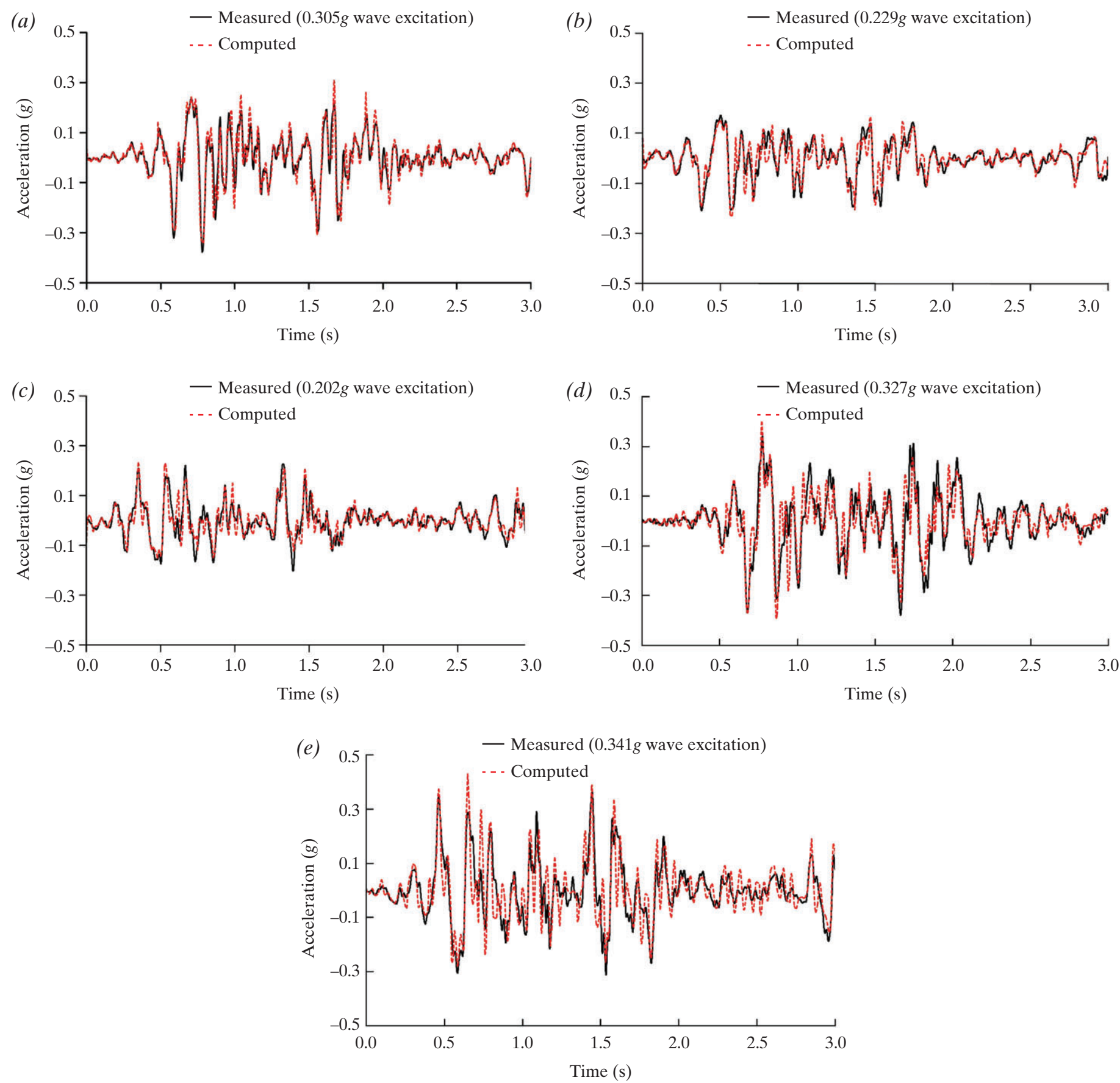

Fig. 8: Comparison of roof acceleration time histories at the start of cracking. (a) SW1, (b) SW2, (c) SW3, (d) SW4 and (e) SW5 

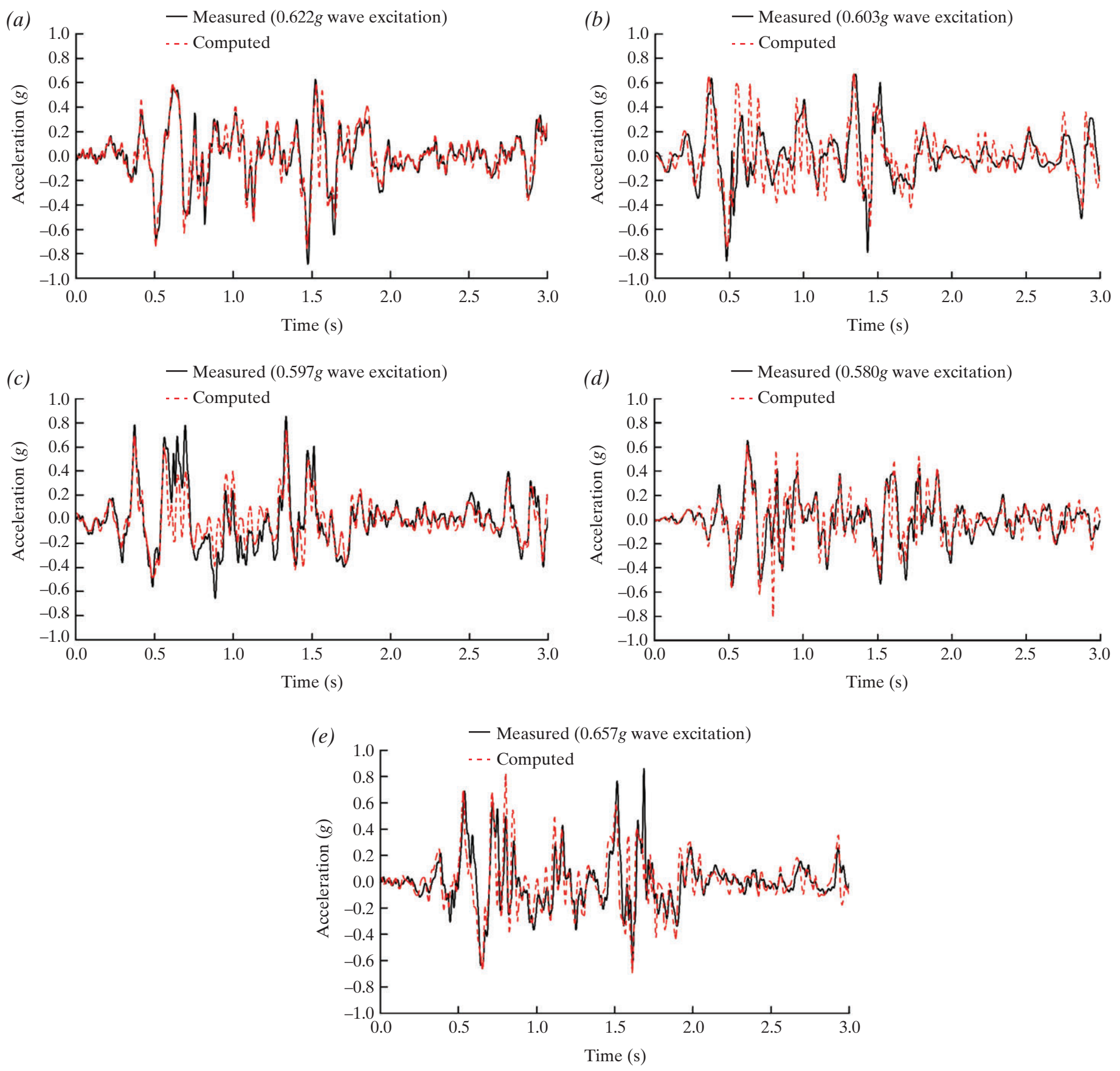

Fig. 9: Comparison of roof acceleration time histories after cracking. (a) SW1, (b) SW2, (c) SW3, (d) SW4 and (e) SW5

\section{Conclusions}

1. The initial stiffness of the lowrise shear walls made of RAC was weaker than that of the shear wall made of NAC. After the concrete cracking, the stiffness degradation of the low-rise shear walls increased with the increase in the recycled aggregate replacement ratio, resulting in an increase in the reduced degree of natural frequency. The concealed bracings had no significant effect on the initial stiffness of the low-rise shear walls made of RAC. But after the concrete cracking, the stiffness decrement of the low-rise shear wall with concealed bracings was slower than that of the shear walls without concealed bracings.

2. When initial cracks appeared, the shaking table's peak acceleration of the low-rise shear walls made of RAC was lower than that of the shear wall made of natural aggregate concrete, and the reduced degree increased with the increase in recycled aggregate replacement ratio. The situation was found to improve by increasing the reinforcement ratio, especially by installing concealed bracings.

3. During the failure of the shear walls, when the level of ground motion was basically the same, the lateral drift response of the shear walls made of RAC was greater than that of the shear wall made of NAC, and the drift responses increased as the ratio of the recycled aggregate replacement increased. The use of concealed bracings in low-rise shear walls was found to reduce the lateral drift response.

4. Under the same peak acceleration of shaking table, the damage degree of the low-rise shear wall made of recycled coarse aggregate concrete was close to that of the shear wall made of NAC. The damage degree of the low-rise shear wall made of recycled coarse aggregate and recycled fine aggregate concrete was relatively severe. If more reinforcements are 
used in the low-rise shear wall made of RAC, more cracks would appear with smaller widths. The concealed bracings in low-rise shear wall made of RAC restricted the development of the diagonal cracks, as the results of the lateral load-carrying and deformation capacity of the shear wall were significantly improved.

5. Compared with the low-rise shear wall made of NAC, the seismic capacity of the low-rise shear wall made of recycled coarse aggregate concrete was relatively weaker but still met the requirements of seismic design. The concealed bracings were able to greatly improve the seismic capacity of the low-rise shear walls made of RAC and they were suitable for use in structures made of RAC.

\section{Acknowledgements}

The authors are grateful for the funding provided by the Beijing Natural Science Foundation (8132016) and Key Laboratory of Urban Security and Disaster Engineering MOE, Beijing University of Technology.

\section{References}

[1] Ajdukiewicz AB, Kliszczewicz AT. Comparative tests of beams and columns made of recycled aggregate concrete and natural aggregate concrete. J. Adv. Concr. Technol. 2007; 5(2): 259-273.

[2] Xiao JZ, Li WG, Fan YH, Xiao H. An overview of study on recycled aggregate concrete in China. Constr. Build. Mater. 2012; 31: 364-383.

[3] Chinese Standard. JGJ/T240-2011: Technical Specification for Application of Recycled Aggregate [in Chinese]. Building Industry Press: Beijing: China,2011.
[4] Xiao JZ, Li JB, Zhang C. Mechanical properties of recycled aggregate concrete under uniaxial loading. Cem. Concr. Res. 2005; 35: 1187-1194.

[5] Xiao JZ, Falkner H. Bond behaviour between recycled aggregate concrete and steel rebars. Constr. Build. Mater. 2007; 21: 395-401.

[6] Tabsh SW, Abdelfatah AS. Influence of recycled concrete aggregates on strength properties of concrete. Constr. Build. Mater. 2009; 3(2): 1163-1167.

[7] Belén GF, Fernando MA, Diego CL, Sindy SP. Stress-strain relationship in axial compression for concrete using recycled saturated coarse aggregate. Constr. Build. Mater. 2011; 25(5): 2335-2342.

[8] Sato R, Maruyama I, Sogabe T, Sogo M. Flexural behavior of reinforced recycled aggregate concrete beam. J. Adv. Concr. Technol. 2007; 5(1): 43-61.

[9] Bai GL, Liu C, Zhao HJ. Experimental research on seismic behavior of recycled concrete frame columns [in Chinese]. J. Earthquake Eng. Vib. 2011; 31(1): 61-66.

[10] Corinaldesi V, Letelier V, Moriconi G. Behaviour of beam-column joints made of recycled-aggregate concrete under cyclic loading. Constr. Build. Mater. 2011; 25(4): 1877-1882.

[11] Cao WL, Dong HY, Zhang JW. Study on seismic performance of RAC shear wall with different shear-span ratio. In Proceedings of the 2nd International Conference on Waste Engineering and Management, Shanghai, China, 2010; pp. 652-660

[12] Xiao JZ, Sun YD, Falkner H. Seismic performance of frame structures with recycled aggregate concrete. Eng. Struct. 2006; 28: 1-8.

[13] Cao WL, Yin HP, Zhang JW, Dong HY, Zhang YQ. Seismic behavior experiment of recycled concrete frame structures [in Chinese]. J. Beijing Univ. Technol. 2011; 37(2): 191-198.

[14] Cao WL, Zhang JW, Yin HP, Chen JL. Experimental study on the seismic behavior of recycled concrete frame-shear-wall structure [in Chinese]. Eng. Mech. 2010; 27(SII): 135-141.
[15] Cao WL, Xue SD, Zhang JW. Seismic performance of RC shear wall with concealed bracing. Adv. Struct. Eng. 2003; 6(1): 1-13.

[16] Chinese Standard. GB/T 25176-2010: Recycled Fine Aggregate for Concrete and Mortar [in Chinese]. Standards Press of China: Beijing, 2011.

[17] Chinese Standard. GB/T 25177-2010: Recycled Coarse Aggregate for Concrete [in Chinese]. Standards Press of China: Beijing, 2011.

[18] Chinese Standard. GB50011-2010: Code for Seismic Design of Buildings [in Chinese]. Building Industry Press: Beijing, China, 2011.

[19] Mazars J, Kotronis P, Davenne L. A new modelling strategy for the behaviour of shear walls under dynamic loading. Earthq. Eng. Struct. Dyn. 2002; 31(4): 937-954.

[20] Ghobarah A, Youssef M. Modelling of reinforced concrete structural walls. Eng. Struct. 1999; 21: 912-923.

[21] Massone LM, Orakcal K, Wallace JW. Modeling of squat shearwalls controlled by shear. ACI Struct. 2009; 106(5): 646-655.

[22] Martinelli L, Martinelli P, Mulas MG Performance of fiber beam-column elements in the seismic analysis of a lightly reinforced shear wall. Eng. Struct. 2013; 49: 345-359.

[23] Thomson ED, Perdomo ME, Picón R, Marante ME, Flórez-López J. Simplified model for damage in squat RC shear walls. Eng. Struct. 2009; 31: 2215-2223.

[24] Hibbitt, Karlsson \& Sorensen, Inc. ABAQUS/Standard User's Manual (Version 6.1). Habbitt, Karlsson \& Sorensen, Inc., USA 2000.

[25] Chinese Standard. GB50010-2010: Code for Design of Concrete Structures [in Chinese]. Building Industry Press: Beijing, China, 2011.

[26] Zhuang Z, You XC, Liao JH, Cen S, Shen XP, Liang MG. FEM Analysis and Application Based on ABAQUS [in Chinese]. Tsinghua University Press: Beijing, 2009.

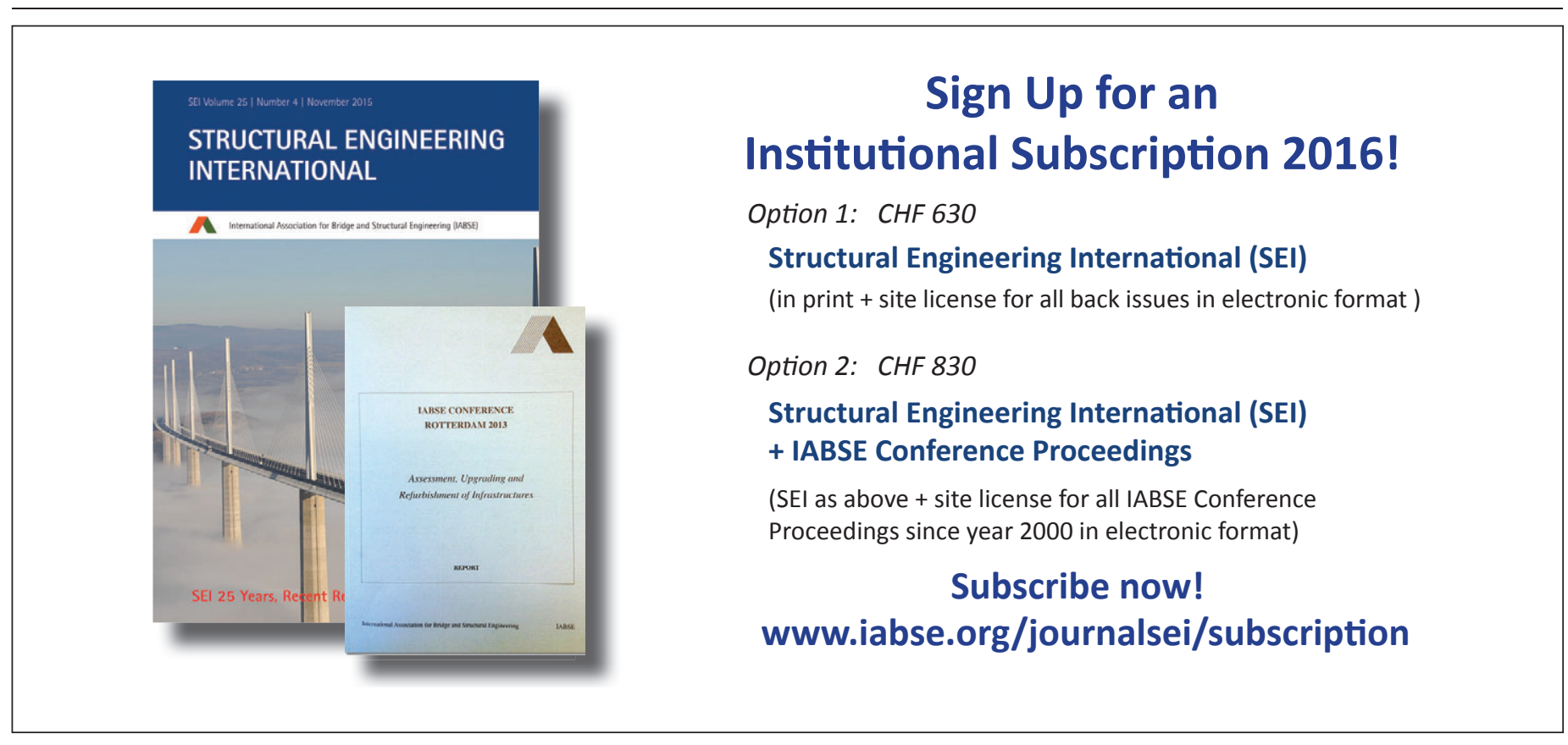

